\title{
Timing of Glyphosate Applications to Wheat Cover Crops to Reduce Onion Stunting Caused by Rhizoctonia solani
}

Dipak Sharma-Poudyal, Former Postdoctoral Research Associate, Washington State University, Pullman 99164; Timothy C. Paulitz, Plant Pathologist, United States Department of Agriculture-Agricultural Research Service, Pullman, WA 99164; and Lindsey J. du Toit, Professor, Washington State University, Mount Vernon Northwestern Washington Research and Extension Center, Mount Vernon 98273

\begin{abstract}
Sharma-Poudyal, D., Paulitz, T. C., and du Toit, L. J. 2016. Timing of glyphosate applications to wheat cover crops to reduce onion stunting caused by Rhizoctonia solani. Plant Dis. 100:1474-1481.

Stunting caused by Rhizoctonia spp. is economically important in irrigated onion bulb crops in the semiarid Columbia Basin of Oregon and Washington, where cereal winter cover crops commonly are planted the previous fall to prevent wind erosion of soil. The cover crop is killed with herbicide application just before or shortly after onion seeding, so that the dead rows of cereal plants provide a physical barrier tall enough to protect onion seedlings against wind and sand blasting but not tall enough to shade onion seedlings. However, the cover crop also serves as a green bridge for Rhizoctonia spp. on cereal roots to colonize the onion roots, potentially resulting in severe stunting of onion seedlings. To determine the effect of timing of application of the herbicide glyphosate to reduce this green bridge effect and, subsequently, onion stunting, three herbicide application intervals preceding onion planting were evaluated in a grower's onion field in each of 2012 and 2014 in the Columbia Basin. The wheat cover crop was killed with a glyphosate application 27,17 , and 3 days before onion seeding in 2012 and 19, 10, and 3 days before seeding in 2014. As the interval between herbicide application and onion

planting increased from 3 days to 19 and 27 days, the number of patches of stunted onion plants decreased by $\geq 55 \%$, total area of stunted patches decreased by 54 to $63 \%$, and patch severity index decreased by 59 to $65 \%$. Similarly, the Rhizoctonia solani AG 8 DNA concentration in soil sampled from the dead cover crop rows declined as the interval between glyphosate application and onion seeding increased in the 2012 trial but not in the 2014 trial. $R$. solani AG 3 and AG 8 DNA concentrations in soil sampled from the cover crop rows were significantly positively correlated with the number of patches of stunted onion plants $(r=0.490$ and 0.607 at $P=0.039$ and 0.008 , respectively), total area of stunted patches $(r=0.496$ and 0.659 at $P=0.035$ and 0.003 , respectively), and patch severity index $(r=0.492$ and 0.635 at $P=0.038$ and 0.005 , respectively) in the 2012 trial; however, these variables were only correlated significantly with $R$. solani AG 3 DNA concentration in the 2014 trial. Increasing the interval between herbicide application to the cover crop and onion planting provides a practical management tool for stunting in onion bulb crops.
\end{abstract}

The Columbia Basin of central Washington State and north-central Oregon State is an important area for onion (Allium cepa L.) bulb production, accounting for $27 \%$ of the total onion bulb acreage in the United States on 13,300 ha in 2012 (United States Department of Agriculture National Agricultural Statistics Service 2012). Onion plants are grown in the Columbia Basin under irrigation in 3- to 4-year rotations with carrot (Daucus carota L.), pea (Pisum sativum L.), potato (Solanum tuberosum L.), sweet corn (Zea mays L.), various small grains such as wheat (Triticum aestivum L.), and other crops (Pelter and Sorensen 2003). Onion crops are primarily direct seeded from late February to mid-April, although field preparation for onion seeding starts during the prior fall, when many onion growers plant cover crops. The predominant sandy soils with low organic matter in many parts of the Columbia Basin, combined with strong winds each spring and fall, can cause sand blasting of emerging onion seedlings, potentially necessitating replanting of entire fields (Hosler 1983; Johnson and Makinson 1988). Shallow-rooted, succulent onion seedlings are very susceptible to wind and sand

Current address of D. Sharma-Poudyal: Plant Health Program, Oregon Department of Agriculture, Salem 97301.

Corresponding author: L. J. du Toit; E-mail: dutoit@wsu.edu

This research was supported by the Washington State Department of Agriculture Specialty Crop Block Grant Number K525; and PPNS number 0700, Department of Plant Pathology, College of Agricultural, Human, \& Natural Resource Sciences, Agricultural Research Center, Hatch Project Number WNP05595, Washington State University, Pullman, WA 99164-6430.

Accepted for publication 11 January 2016.

http://dx.doi.org/10.1094/PDIS-10-15-1234-RE

(C) 2016 The American Phytopathological Society blasting. Therefore, a fall-sown cover crop, typically winter wheat, usually is planted on the sandier fields in this region to serve as a physical barrier to mitigate the effects of sand blasting on onion seedlings. When the cereal cover crop is tall enough to provide a physical barrier to sand blasting but not tall enough to shade the developing seedlings, the cover crop is killed with application of an herbicide, usually glyphosate (Sharma-Poudyal et al. 2013a,d). The timing of herbicide application can range from more than a month prior to seeding (e.g., if winter conditions are warm enough that the cover crop reaches optimum size earlier than normal) to up to 2 weeks after onion seeding (e.g., if cold winter temperatures slow growth of the cover crop significantly). Onion seed usually are planted in double rows on beds, with rows of the dead or dying cereal cover crop between the double rows of onion to provide a protective wind barrier (Sharma-Poudyal et al. 2013a).

The effects of herbicide applications to cover crops or weeds on subsequent soilborne plant diseases or plant pathogens has been studied (Babiker et al. 2011; Duke et al. 2007; Lévesque and Rahe 1992; Smiley et al. 1992). Root rot caused by Rhizoctonia spp., one of the most common soil-inhabiting fungi (Sneh et al. 1991), is often more prevalent in crops planted soon after application of glyphosate to a field, as has been documented for canola (Brassica napus L.) (Rashid et al. 2013), barley (Hordeum vulgare L.) (Babiker et al. 2011; Smiley et al. 1992), onion (Sharma-Poudyal et al. 2013a,d, 2015b), pea (Sharma-Poudyal et al. 2015c), sugar beet (Beta vulgaris L.) (Larson et al. 2006), and wheat (Baley et al. 2009). When glyphosate acts on plants, inherent defense responses of the plant are compromised, and Rhizoctonia spp. can colonize the dying roots rapidly (Babiker et al. 2011; Johal and Huber 2009). As a result, severity of root rot caused by Rhizoctonia spp. may increase on subsequent crops planted in close proximity to the dying or dead roots (Babiker et al. 2011; Sharma-Poudyal et al. 2013a,d). In the Columbia Basin, patches of stunted plants in onion (Sharma-Poudyal et al. 2013a,d) and pea (Sharma-Poudyal et al. 2015c) crops associated with herbicide 
application to the preceding cereal cover crop appear to be caused primarily by isolates of Rhizoctonia solani anastomosis group (AG) 2, AG 4, and AG 8. R. solani AG 8 also is known to be a common cause of root rot or bare patch of barley and wheat in the U.S. Pacific Northwest (Paulitz et al. 2002), and has been documented as the primary cause of patches of stunted plants in onion crops in Australia (Wicks et al. 2011).

Onion stunting associated with herbicide applications to cereal cover crops first becomes visible as patches of stunted onion plants at the three- to five-true-leaf stage of growth (Sharma-Poudyal et al. 2015b). The diameter of these patches can range from $<1$ to $>25 \mathrm{~m}$, and may account for $\leq 15 \%$ of the area of a crop (du Toit et al. 2012; Wicks et al. 2011). Onion stunting can reduce bulb size and marketable yield significantly (Anstis et al. 2012; du Toit et al. 2012; Sharma-Poudyal et al. 2013c, 2015b) but does not affect plant stands (Sharma-Poudyal et al. 2013c, 2015b). Compared with adjacent healthy areas, stunting can cause up to $78 \%$ reduction in onion bulb yield within patches of stunted plants in the Columbia Basin (Sharma-Poudyal et al. 2013c, 2015b).

Storage-type onion bulb crops in the Pacific Northwest have an estimated farmgate value of $\$ 13,500 /$ ha (United States Department of Agriculture National Agricultural Statistics Service 2012). Host resistance (Sharma-Poudyal et al. 2015a), biological control (SharmaPoudyal et al. 2014b), fungicides (Sharma-Poudyal et al. 2013b), and cultural methods of control (Sharma-Poudyal et al. 2013a,d, 2014a) have been evaluated to manage onion stunting in the Columbia Basin. Onion cultivars commonly grown in the Columbia Basin appear to be susceptible to this disease (Sharma-Poudyal et al. 2015b); and, among 35 promising, advanced onion lines evaluated by SharmaPoudyal et al. (2015a), only 4 were partially resistant to $R$. solani AG 8 . Although deep plowing reduced the severity of onion stunting compared with shallow tillage in a field trial in the Columba Basin (Sharma-Poudyal et al. 2014a), onion growers are reluctant to use deep plowing in commercial farming because of the potential negative effects of this practice on soil quality and erosion (Schillinger et al. 2010). As an alternative management practice, banded, preplant, incorporated application of the fungicide azoxystrobin has been demonstrated to reduce the severity of onion stunting, and has been adopted by some growers in the Columbia Basin (du Toit et al. 2012; SharmaPoudyal et al. 2013b, 2015b).

Increasing the duration between herbicide applications for weed control and planting barley crops resulted in a reduction in severity of barley root rot caused by Rhizoctonia spp. in the U.S. Pacific Northwest (Babiker et al. 2011; Smiley et al. 1992). Because winter cereal crops, primarily winter wheat, are planted commonly as cover crops in the onion production region of the Columbia Basin, a similar reduction in onion stunting might be achieved by increasing the interval between herbicide application to cereal cover crops and seeding of onion bulb crops. Therefore, the objective of this research was to determine the potential effects of the interval between herbicide application to a winter wheat cover crop and subsequent onion planting on the severity of onion stunting, as well as the concentration of DNA in soil for $R$. solani AGs associated most commonly with onion stunting in the Columbia Basin.

\section{Materials and Methods}

Field experiments. Field experiments were performed in 2012 and 2014 to assess the effects of three preplant application intervals of glyphosate to a winter wheat cover crop before planting onion bulb crops on the development of stunting in the onion crops associated with $R$. solani. Each trial was completed in a grower-cooperator onion field in the Columbia Basin of south-central Washington using a randomized complete block design, with six replications of the three intervals of herbicide application. The 2012 trial was completed in a field near Paterson, WA and the 2014 trial in a field near Benton City, WA. Each field was irrigated by center pivot and measured approximately 50 ha. Each plot was $6.7 \mathrm{~m}$ wide ( 12 beds at $1.8 \mathrm{~m} / \mathrm{bed}$, with each bed consisting of two double rows of onion), and the entire length of the center-pivot irrigated field ranged from 831 to $874 \mathrm{~m}$ in the 2012 trial and 678 to $785 \mathrm{~m}$ in the 2014 trial. For each field, standard agronomic practices were used for cover cropping and onion bulb production in the Columbia Basin (Pelter and Sorensen 2003). The dates of cover crop planting, herbicide application, soil sampling, and onion disease assessment in each trial were based on local weather conditions, grower preference, or cover crop and onion crop maturity. The summer was warmer in 2014 than 2012; therefore, soil sampling and onion stunting assessment were completed earlier in 2014 than in 2012.

For the 2012 trial, seed of the winter wheat cultivar Stephens was planted by the grower-cooperator in October 2011, at a row spacing of $1.8 \mathrm{~m}$. GlyStar Plus (41\% glyphosate; Albaugh, Inc., Ankeny, IA) was applied to the cover crop by the grower at 3.5 liters/ha on 22 March, 2 April, and 16 April 2012, using a spray boom. These dates equated to 27,17 , and 3 days, respectively, before the grower planted seed of the onion cultivar Cometa on 19 April 2012. For the 2014 trial, Stephens winter wheat was seeded in October 2013 by the grower-cooperator, as described for the 2012 trial. The grower applied AgriSolutions Cornerstone Plus (41\% glyphosate; Winfield Solutions, LLC, St. Paul, MN) to the cover crop at 2.3 liters/ha on 6 April, and 2.9 liters/ha each on 15 and 22 April 2014, using a spray boom. These dates equated to 19,10 , and 3 days, respectively, before planting Cometa onion seed on 25 April 2014.

Soil sampling. Soil samples were collected from each plot by sampling within the rows of dead or dying cover crop and from within the adjacent onion rows in the middle of each plot, to determine DNA concentration of $R$. solani AG 2-1, AG 3, AG 4, and AG 8. In the 2012 trial, sampling was done at the four-true-leaf stage of the onion crop (11 June 2012). Due to detection of greater concentrations of $R$. solani AG 8 in the wheat rows than the onion rows, and the inverse relationship between $R$. solani AG 8 DNA and herbicide application interval in the 2012 trial, DNA concentration of $R$. solani AG was determined only from the wheat rows in the 2014 trial. In the 2014 trial, sampling was done at the one-true-leaf stage of the onion crop (12 May 2014). In each trial, soil was collected every 8 and $12 \mathrm{~m}$ along the length of each plot in 2012 and 2014, respectively, to a depth of $10 \mathrm{~cm}$ using a $2.5-\mathrm{cm}$-diameter soil probe. This resulted in a total of 36 and 18 soil samples collected per plot in the 2012 and 2014 trials, respectively. The soil cores were pooled for each plot, and the composite soil sample (approximately $1 \mathrm{~kg}$ ) was dried overnight at $45^{\circ} \mathrm{C}$ DNA of each the four $R$. solani AGs listed above was then quantified from $450 \mathrm{~g}$ of each dried soil sample at the South Australia Research and Development Institute in Urrbrae, Australia. This facility has developed a proprietary soil DNA extraction and quantification protocol from as much as $450 \mathrm{~g}$ of soil per sample (Ophel-Keller et al. 2008).

Onion stunted patch severity ratings. The eight center beds per plot were rated for severity of onion stunting at the five-true-leaf growth stage (20 June) and again at the seven-true-leaf stage of growth (3 July) of the onion crop in the 2012 trial. In the 2014 trial, severity of onion stunting was rated at the three-true-leaf stage (16 June) and the five-true-leaf stage ( 2 July). The number of patches in each plot was counted, and the length and width of each patch was measured to estimate the area of each patch. In addition, the average severity of stunting of onion plants in each patch was rated on a 1-to-3 scale, where $1=$ at least $50 \%$ of the plants in the patch were $<33 \%$ shorter than adjacent, healthy plants outside the patch; $2=$ at least $50 \%$ of the plants in the patch were stunted 33 to $66 \%$; and $3=$ at least $50 \%$ of the plants were stunted $>66 \%$ (Sharma-Poudyal et al. 2015b).

Data analysis. The number of patches of stunted plants per plot, cumulative patch area per plot, mean severity of stunting in the patches, and mean patch severity index were standardized to a perhectare basis by accounting for the variation in size of the plots in each trial, given the circular shape of each field. The patch severity index was then calculated as the mean of the product of (patch severity) $\times$ (patch area) for all patches of stunted onion plants in a plot. Analyses of variance (ANOVA) were calculated for the means comparison for DNA concentrations of each $R$. solani AG detected in soil sampled from the onion rows and wheat cover crop rows. DNA concentration means were compared using Fisher's protected least significant difference at $P=0.05$. Disease variables and DNA concentration of each $R$. solani AG were regressed with treatments (herbicide application interval before onion seeding) for each trial. 
Pearson's correlation coefficients were calculated for DNA concentration of each of the four $R$. solani AGs with each disease variable. Data were transformed, if needed, to satisfy the assumptions of parametric analysis (homogeneous variances and normal distribution of residuals).

\section{Results}

Effects of the interval between glyphosate application and onion seeding on onion stunting: 2012 trial. The number of stunted patches in the 2012 trial averaged $98 \pm 11 /$ ha (mean \pm standard error) and ranged from 32 to $216 /$ ha at the first rating completed at the five- true-leaf stage, compared with $40 \pm 6 /$ ha and a range of 5 to $77 /$ ha at the second rating at the seven-true-leaf stage. Similarly, the mean total area of stunted patches was $143 \pm 6 \mathrm{~m}^{2} /$ ha and ranged from 35 to $295 \mathrm{~m}^{2} / \mathrm{ha}$ at the first rating, and averaged $83 \pm 12 \mathrm{~m}^{2} / \mathrm{ha}$ with a range from 5 to $164 \mathrm{~m}^{2} / \mathrm{ha}$ at the second rating. Patch severity index ranged from 43 to 484 with a mean of $239 \pm 35$ at the five-true-leaf stage, and ranged from 4 to 290 with a mean of $126 \pm 19$ at the seven-true-leaf stage. Onion stunting was greater at the five-true-leaf stage than at the seven-true-leaf stage because onion crops reach a maximum canopy height in late June to mid-July in the Columbia Basin, after which the
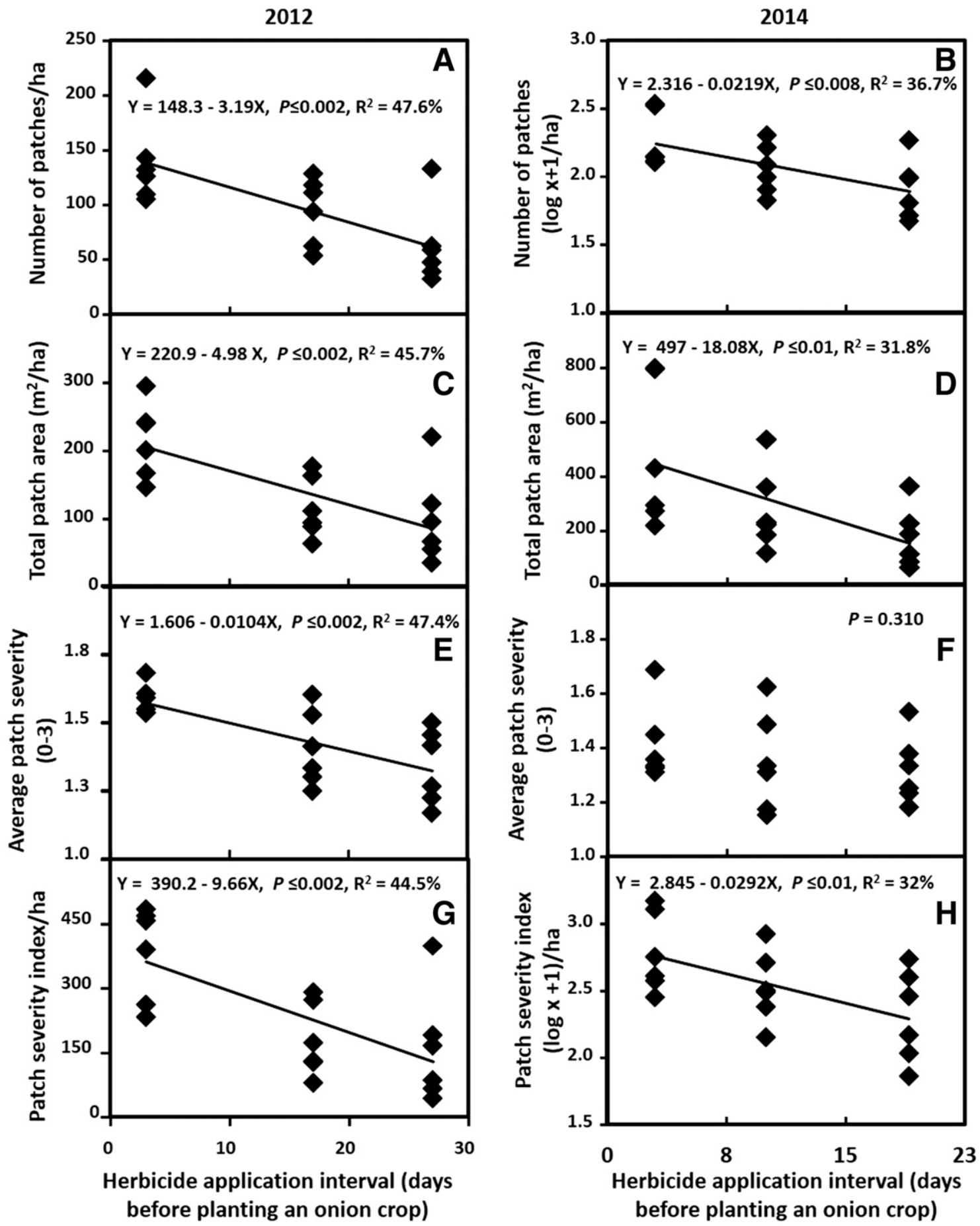

Fig. 1. Regression relationship for the interval between glyphosate application to a wheat cover crop and planting onion seed, measured in days before onion seeding, with onion stunting evaluated in onion bulb crops located near Paterson, WA in 2012 (A, C, E, and G) and Benton City, WA in 2014 (B, D, F, and H) (details of the experiment are described in the main text). $Y=$ the dependent variable (measure of onion stunting), $X=$ the number of days between glyphosate application to the wheat cover crop and planting of the onion crop, $P=$ probability of the linear regression equation not being significant, and $R^{2}=$ regression coefficient. The regression equation for average patch severity in the 2014 onion crop (F) was not significant. For each field trial, each data point is the mean of six replicate plots. Refer to the main text for details on soil sampling, DNA extraction, DNA quantification, and disease assessment. 
primary growth is bulb size. Therefore, stunted plants in patches eventually reach the same height as the rest of the crop.

Because stunting in the 2012 trial was greatest at the five-true-leaf stage rating, regression analysis results for rating at the five-true-leaf stage are presented (Fig. 1). The longer the interval between glyphosate application and onion seeding, the fewer stunted patches $(F=$ 14.5 at $P=0.002$ based on the ANOVA), the less the total area of stunted plants $(F=13.5$ at $P=0.002)$, and the less the average severity of stunting in the patches $(F=14.4$ at $P=0.002)$ and patch severity index $(F=12.8$ at $P=0.002)$ at the five-true-leaf growth stage in the 2012 trial. Application of glyphosate 27 and 17 days before onion seeding reduced the number of patches by 55 and $32 \%$, respectively, compared with plots in which the herbicide was applied just 3 days prior to planting the onion crop (Fig. 1A). Similarly, glyphosate application to the cover crop 27 and 17 days before onion planting reduced the total area of stunted patches per plot by 54 and $46 \%$, respectively (Fig. 1C). The reduction in average patch severity was 16 and $12 \%$ in plots in which glyphosate was applied to the cover crop 27 and 17 days before onion planting, respectively, compared with 3 days before seeding (Fig. 1E). The earlier glyphosate applications also reduced the patch severity index by 59 and 53\%, respectively (Fig. 1G).

Effects of the interval between glyphosate application and onion seeding on onion stunting: 2014 trial. In the 2014 trial, onion stunting was less evident at the first rating completed at the threetrue-leaf growth stage compared with the second rating at the fivetrue-leaf stage (data not shown). The number of stunted patches in the field averaged $47 \pm 10 /$ ha and ranged from 3 to $135 /$ ha at the first rating compared with $137 \pm 20 /$ ha and a range of 46 to $339 /$ ha at the second rating. Total area of stunted patches across the plot was $90 \pm$ $21 \mathrm{~m}^{2} / \mathrm{ha}$ and ranged from 2 to $272 \mathrm{~m}^{2} /$ ha at three-true-leaf growth stage. By the five-true-leaf growth stage, mean total area of stunted patches was $304 \pm 51 \mathrm{~m}^{2} / \mathrm{ha}$ and ranged from 61 to $797 \mathrm{~m}^{2} / \mathrm{ha}$. Similarly, mean patch severity index was $122 \pm 33$ and ranged from 2 to 418 at the three-true-leaf stage compared with $458 \pm 91$ with a range of 71 to 1,479 at the five-true-leaf stage.

Differences in the effects of glyphosate application interval on onion stunting were not evident at the first rating (data not shown). However, by the second rating, the patches of stunted onion plants had become very distinct. The number of stunted patches $(F=9.3$ at $P=0.008$ based on the ANOVA), total area of stunted patches $(F=7.5$ at $P=0.015)$, and patch severity index $(F=7.5$ at $P=$ $0.015)$ decreased progressively as the interval between glyphosate application to the cover crop and onion seeding increased (Fig. 1B, $\mathrm{D}$, and $\mathrm{H}$ ). Only the average severity of stunting was not significant $(F=1.1$ at $P=0.31$; Fig. $1 \mathrm{~F})$. Glyphosate application 19 and 10 days before onion planting resulted in 55 and $40 \%$ reduction in the number of stunted patches, respectively, compared with plots in which the herbicide was applied just 3 days before onion planting (Fig. 1B). The reduction in total area of stunted patches was 63 and $41 \%$ in plots in which the cover crop was treated with herbicide 19 and 10 days before onion seeding, respectively, compared with plots treated with herbicide 3 days before seeding (Fig. 1D). The average severity of stunting in the patches did not correlate significantly with glyphosate application interval prior to onion seeding $(r=-0.25$ at $P=0.31)$, because the average severity of stunting in patches was $1.3,1.3$, and 1.4 in plots in which glyphosate was applied 19, 10, and 3 days before onion seeding, respectively (Fig. 1F). Patch severity index decreased significantly with increasing interval between the glyphosate application to the cover crop and onion planting (Fig. 1H). Glyphosate application 19 or 10 days before onion seeding reduced the patch severity index by 65 or $46 \%$, respectively, compared with plots in which the herbicide was applied just 3 days before onion seeding.

Glyphosate application interval before onion planting versus soil DNA concentration of $R$. solani: 2012 trial. $R$. solani AG 3 DNA was detected from $61 \%$ of the soil samples (11 of 18 plots representing six replications of the three herbicide treatments) collected in the dead wheat cover crop rows, and $50 \%$ of the soil samples ( 9 of 18 plots) from the onion rows (data not shown). Mean concentration of $R$. solani AG 3 DNA detected in soil sampled from the onion rows (12.86 pg/g of soil) versus the cover crop rows (5.00 pg/g of soil) did not differ significantly $(P=0.20$; Table 1$) . R$. solani AG 8 DNA was detected in 72 and $56 \%$ of the soil samples collected from the wheat and onion rows, respectively, in the 2012 trial. The mean concentration of $R$. solani AG 8 DNA detected in the wheat rows $(15.95 \mathrm{pg} / \mathrm{g}$ of soil) was approximately four times greater than that detected in the onion rows (4.19 pg/g of soil) (Table 1). Although the mean DNA concentration of $R$. solani AG 3 was three times greater than that of the $R$. solani AG 8 DNA in the onion rows, the opposite was true for DNA detected in the wheat cover crop rows (i.e., $R$. solani AG 8 DNA concentration was more than three times greater than that of $R$. solani AG 3) The soil DNA concentration detected for $R$. solani AG 3 and AG 8 did not differ significantly (12.86 and $4.19 \mathrm{pg} / \mathrm{g}$ of soil) within the onion rows (Table 2). DNA of $R$. solani AG 2-1 was detected in soil sampled from the wheat rows at an average of only $0.07 \mathrm{pg} / \mathrm{g}$ of soil and was not detected in soil sampled from onion rows (Table 1). DNA of $R$. solani AG 4 was not detected in soil from the wheat or onion rows (Table 1).

Glyphosate application interval before onion planting versus soil DNA concentration of $\boldsymbol{R}$. solani: 2014 trial. In the 2014 trial, $R$. solani AG 2-1 was detected in only $11 \%$ of the plots sampled ( 2 of 18 plots), with each of these two plots containing DNA at an average of only $0.22 \mathrm{pg} / \mathrm{g}$ of soil in the wheat rows (Table 2). $R$. solani AG 3 was detected in soil from $22 \%$ of the plots (4 of 18 plots), and averaged $2.50 \mathrm{pg}$ DNA/g of soil across all 18 plots (Table 2). $R$. solani AG 4 DNA was detected in $89 \%$ of the plots (16 of 18 plots) at an average of $272.67 \mathrm{pg} / \mathrm{g}$ of soil, which was significantly greater than the DNA concentrations of the other three AGs evaluated (Table 2). $R$. solani AG 8 was detected in soil sampled from $72 \%$ of the plots ( 13 of 18 plots) at an average $2.89 \mathrm{pg}$ DNA/g of soil

Table 1. Means comparisons for DNA concentration of Rhizoctonia solani anastomosis groups (AGs) detected in soil sampled within rows of a dead wheat cover crop versus the DNA concentration detected from soil sampled within rows of a live onion crop in a commercial grower's onion bulb crop near Paterson, WA in 2012

\begin{tabular}{lcccc}
\hline & \multicolumn{3}{c}{ Concentration of DNA (pg/g of soil) } \\
\cline { 2 - 5 } $\boldsymbol{R}$. solani AG & Wheat rows & Onion rows & $\boldsymbol{P}$ value $^{\mathbf{y}}$ & LSD $^{\mathbf{z}}$ \\
\hline $2-1$ & 0.07 & 0.00 & 0.30 & 0.15 \\
3 & 5.00 & 12.86 & 0.20 & 12.40 \\
4 & 0.00 & 0.00 & NA & NA \\
8 & 15.95 & 4.19 & $\mathbf{0 . 0 1}$ & 10.30 \\
\hline
\end{tabular}

${ }^{x}$ Refer to the main text for details on soil sampling and DNA extraction and quantification. NA = not applicable because DNA of $R$. solani AG 4 was not detected in either the wheat or onion rows; therefore, a means comparison could not be calculated.

${ }^{\mathrm{y}} \mathrm{F}$ test probability from the analysis of variance. Probabilities $\leq 0.05$ are shown in bold.

${ }^{\mathrm{z}} \mathrm{LSD}=$ Fisher's protected least significant difference tested at $P=0.05$.

Table 2. Means comparisons for DNA concentration of four Rhizoctonia solani anastomosis groups (AGs) detected in soil sampled from rows of a dead wheat cover crop and rows of live onion seedlings in a grower's onion bulb crop near Paterson, WA in 2012 and in dead rows of a wheat cover crop in a growers' onion bulb crop near Benton City, WA in 2014

\begin{tabular}{|c|c|c|c|c|c|c|}
\hline \multirow[b]{3}{*}{ R. solani AG } & \multicolumn{6}{|c|}{ Concentration of DNA (pg/g of soil)y } \\
\hline & \multicolumn{2}{|c|}{$\begin{array}{c}\text { Wheat rows, } \\
2012\end{array}$} & \multicolumn{2}{|c|}{$\begin{array}{c}\text { Onion rows, } \\
2012\end{array}$} & \multicolumn{2}{|c|}{$\begin{array}{c}\text { Wheat rows, } \\
2014\end{array}$} \\
\hline & Mean & Rank & Mean & Rank & Mean & Rank \\
\hline $2-1$ & 0.07 & $24.92 \mathrm{c}$ & 0.00 & $27.00 \mathrm{~b}$ & 0.22 & $21.17 \mathrm{c}$ \\
\hline 3 & 5.00 & $44.53 \mathrm{~b}$ & 12.86 & $46.39 \mathrm{a}$ & 2.50 & $26.58 \mathrm{c}$ \\
\hline 4 & 0.00 & $23.50 \mathrm{c}$ & 0.00 & $27.00 \mathrm{~b}$ & 272.67 & $59.29 \mathrm{a}$ \\
\hline 8 & 15.95 & $53.06 \mathrm{a}$ & 4.19 & $45.61 \mathrm{a}$ & 2.89 & $38.97 \mathrm{~b}$ \\
\hline $\mathrm{LSD}^{\mathrm{z}}$ & $\ldots$ & 8.23 & $\ldots$ & 8.83 & $\ldots$ & 8.72 \\
\hline
\end{tabular}

y Rank-transformed data and ranked values followed by the same letter are not significantly different $(P \leq 0.05)$ based on Fisher's protected least significant difference (LSD). Refer to the main text for details on soil sampling and DNA extraction and quantification.

${ }^{\mathrm{z}} \mathrm{LSD}=$ Fisher's protected least significant difference at $P=0.05$. 
2012

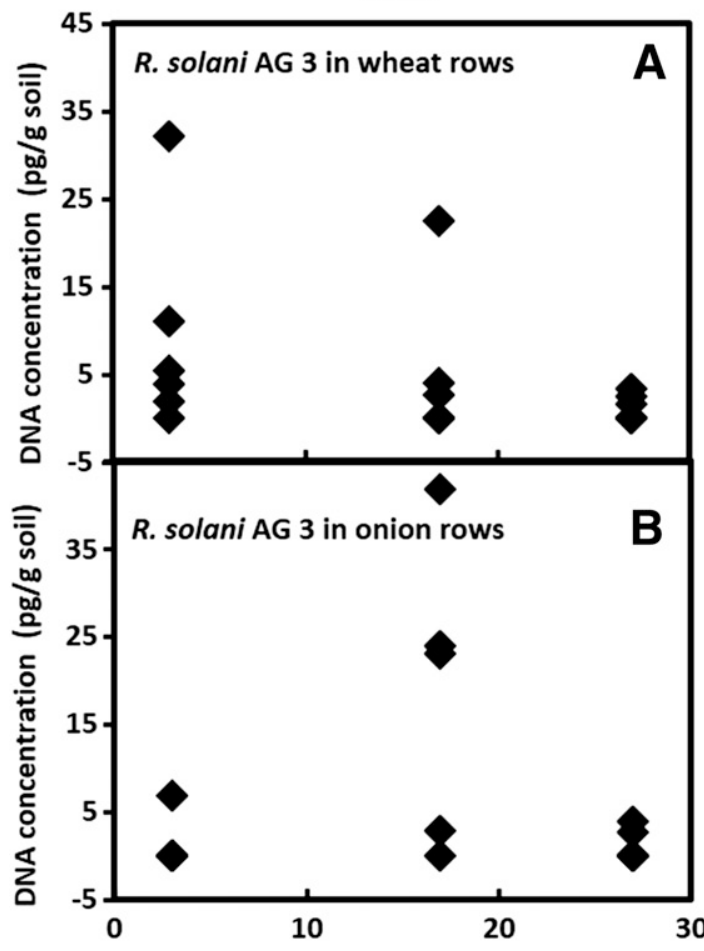

Herbicide application interval (days before onion seeding)

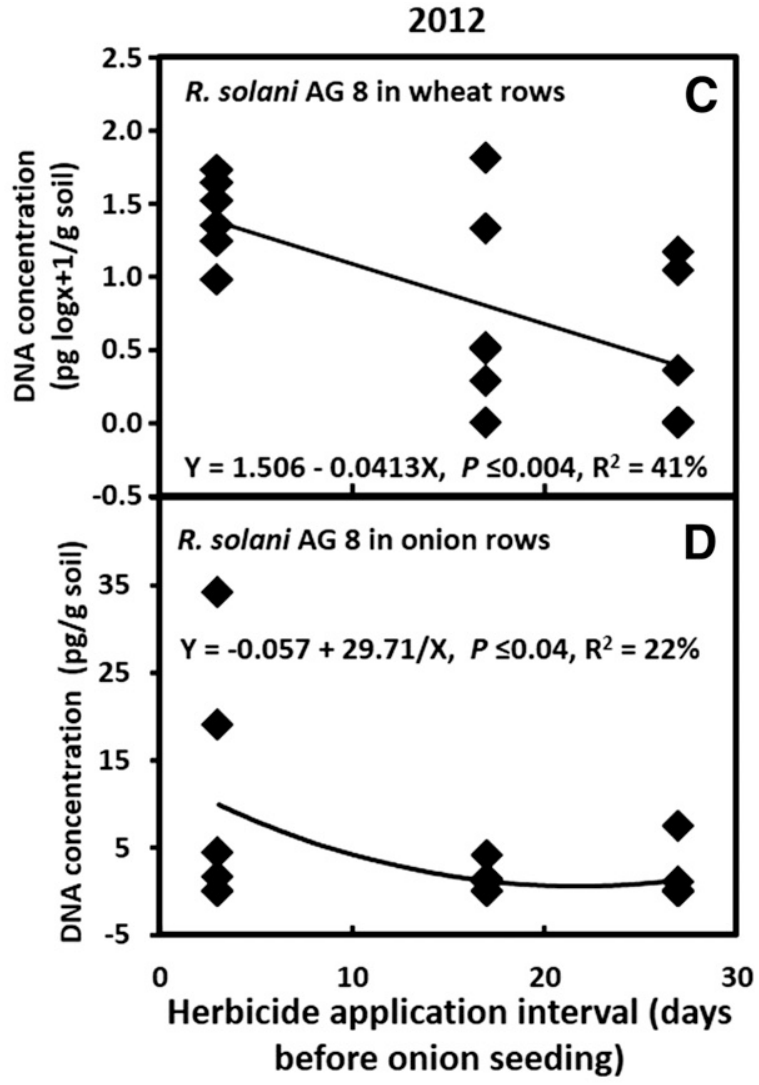

2014

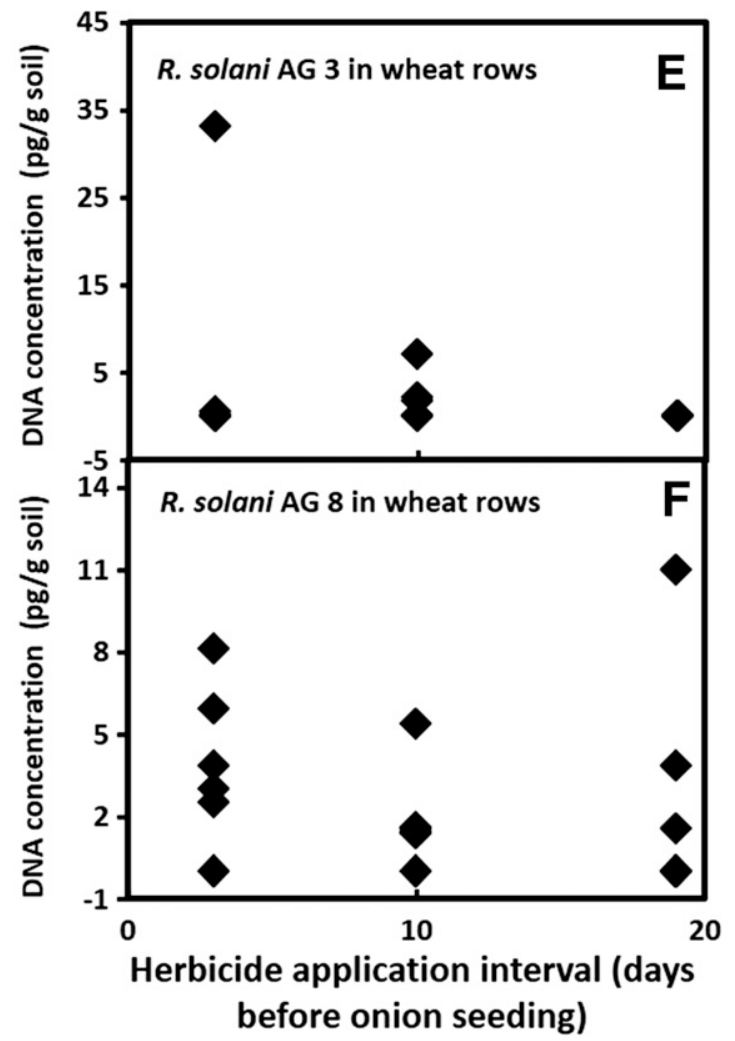

Fig. 2. Regression relationships of the interval between glyphosate application to a wheat cover crop and planting onion seed, measured in days before onion seeding, with DNA concentrations of Rhizoctonia solani AG 3 (A and $\mathbf{B})$ and $A G 8(\mathbf{C}$ and $\mathbf{D})$ detected in soil sampled from rows of the dead wheat cover crop (A and $\mathbf{C})$ and rows of the live onion plants (B and D) in a commercial onion bulb crop near Paterson, WA in 2012; and DNA concentrations of $R$. solani AG 3 (E and F) detected in soil sampled similarly from rows of the dead wheat cover crop in a commercial onion bulb crop near Benton City, WA in 2014. Details of the trial are described in the main text. $Y=$ the dependent variable (DNA concentration), $\mathrm{X}=$ the number of days between glyphosate application to the wheat cover crop and planting of the onion crop, $P=$ probability of the linear regression equation not being significant, and $R^{2}=$ regression coefficient. Only significant regression equations are shown (C). For each field, each data point is the mean of six replicate plots. Refer to the main text for details on soil sampling, DNA extraction, DNA quantification, and disease assessment. 
across the trial. Within the cover crop rows, $R$. solani AG 4 was 109 and 94 times greater in concentration compared with $R$. solani AG 3 and AG 8 DNA, respectively, and the DNA concentration of $R$. solani AG 8 was significantly greater than that of $R$. solani AG 3 and AG 2-1 (Table 2).

The effect of glyphosate application interval prior to onion seeding on concentration of $R$. solani DNA detected in soil sampled from the cover crop rows was significant for $R$. solani AG 8 in 2012 (Fig. 2C) but not in 2014 (Fig. 2F). The interval between glyphosate application to the cover crop and onion seeding did not affect the DNA concentration of $R$. solani AG 3 detected in soil sampled from the wheat or onion rows in the 2012 trial (Fig. 2A and B) or in the wheat rows in the 2014 trial (Fig. 2E). The relationships between herbicide application interval and onion planting with soil DNA concentration of $R$. solani AG 8 in the wheat and onion rows was defined best by a simple linear regression equation (Fig. 2C) and a first-degree inverse linear model (Fig. 2D), respectively, in the 2012 trial but was not significant in the 2014 trial (Fig. 2F).

Correlation between concentration of $R$. solani DNA detected in soil samples and onion stunting. Correlation analysis for the 2012 trial revealed a significant positive association between the amount of DNA of each of $R$. solani AG 3 and AG 8 detected in soil sampled from the wheat rows with the measures of onion stunting ( $r=0.490$ to 0.496 at $P=0.008$ to 0.035 for $R$. solani AG 3, and $r=$ 0.607 to 0.659 at $P=0.008$ to 0.003 for $R$. solani AG 8; Table 3 ). For soil sampled from the onion rows, the DNA concentration of $R$. solani AG 3 did not correlate significantly with any measure of onion stunting but the concentration of $R$. solani AG 8 DNA was correlated significantly with the total area of stunted patches of onion plants $(r=$ 0.468 at $P=0.050)$ and patch severity index $(r=0.492$ at $P=0.038)$ (Table 3). In the 2014 trial, in which DNA concentration of the $R$. solani AGs was quantified only from the cover crop rows, the DNA concentration detected for $R$. solani AG 3 increased significantly with an increase in the number of patches $(r=0.599$ at $P=0.009)$, total area of stunted patches $(r=0.608$ at $P=0.007)$, and patch severity index $(r=0.567$ at $P=0.014)$. $R$. solani AG 2-1 was detected in soil from only two cover crop rows sampled, with no significant correlation between DNA concentration detected and the onion stunting variables measured (Table 3). Likewise, the DNA concentrations of $R$. solani AG 4 and AG 8 detected in the wheat cover crop rows were not correlated significantly with any measure of onion stunting (Table 3 ).

\section{Discussion}

In two onion bulb crops in the Columbia Basin of central Washington, the longer the interval between application of glyphosate to the winter wheat cover crop and planting of the onion crop, the greater the reduction in onion stunting associated with $R$. solani. Glyphosate application to the cover crop 19 to 27 days before onion seeding significantly reduced the number of patches of stunted onion plants by at least $55 \%$, total area of stunted patches by 54 to $63 \%$, and patch severity index by 59 to $65 \%$ compared with plots in which the herbicide application was done just 3 days before planting onion seed. This demonstrated that earlier applications of glyphosate to cereal cover crops can be important for reducing the negative impact of onion stunting. Similar trends in reduction in Rhizoctonia root rot of barley were observed with increased glyphosate application interval in fields in the U.S. Pacific Northwest (Babiker et al. 2011; Smiley et al. 1992). A minimum of 21 to 42 days between herbicide application and planting was suggested to manage Rhizoctonia root rot of wheat (Roget et al. 1987) and at least 11 to 27 days for barley (Babiker et al. 2011). Although the minimum days between herbicide application and onion planting required to prevent onion stunting completely was not determined in the onion trials in this study, glyphosate application more than 27 days before onion seeding may result in even greater reduction in onion stunting.

The difference in numbers of patches of stunted onion plants, cumulative area of stunted patches, and stunting severity observed at the five- versus seven-true-leaf stage of onion growth in the 2012 trial and the three- versus five-true-leaf stage of onion growth in the 2014 trial highlighted the importance of timing the disease rating based on crop growth stage under field conditions. In the 2012 trial, disease ratings at the five-true-leaf stage revealed 144,72 , and $4 \%$ greater number of stunted patches, total area of stunted patches, and disease severity, respectively, compared with disease ratings done at the seven-trueleaf stage of the onion crop. In 2014, $192 \%$ more stunted patches, $237 \%$ greater area of stunted patches, and $16 \%$ more severe onion stunting were observed at the five-true-leaf stage compared with the three-true-leaf stage. Given the reduction in onion stunting observed at the seven- versus five-true-leaf onion growth stages in the 2012 trial, onion stunting was rated at the three- and five-true-leaf stages in the 2014 trial. However, onion plants at the three-true-leaf growth stage in 2014 were not tall enough to reveal the presence of stunted patches. Onion plants with low stunting severity ratings eventually catch up in growth with nonstunted plants as the crop matures, as shown by the fact that stunting in patches with ratings of 1 usually is no longer evident by late June to mid-July, depending on the season (SharmaPoudyal et al. 2015b). This might explain why rating onion stunting at the seven-true-leaf stage in the 2014 trial underestimated disease compared with rating at the five-true-leaf stage. Based on these observations, rating onion crops in the Columbia Basin for stunting at

Table 3. Pearson's correlation coefficients for DNA concentration of Rhizoctonia solani anastomosis groups (AGs) detected in soil sampled from rows of a dead wheat cover crop and rows of a live onion bulb crop located near Paterson, WA in 2012; and in soil sampled from dead rows of a wheat cover crop in an onion bulb crop located near Benton City, WA in 2014 versus the severity and total area of patches of stunted onion plants caused by $R$. solani ${ }^{\mathrm{y}}$

\begin{tabular}{|c|c|c|c|c|}
\hline R. solani AG & $\begin{array}{l}\text { Crop rows from which } \\
\text { soil was sampled }\end{array}$ & $\begin{array}{l}\text { Number of patches of stunted } \\
\text { onion plants/ha }\end{array}$ & $\begin{array}{l}\text { Cumulative area of patches of stunted } \\
\text { onion plants }\left(\mathrm{m}^{2} / \mathrm{ha}\right)\end{array}$ & Patch severity index/ha \\
\hline \multicolumn{5}{|l|}{2012} \\
\hline \multirow[t]{2}{*}{$2-1$} & Wheat & NA & $\ldots$ & $\ldots$ \\
\hline & Onion & NA & $\ldots$ & $\ldots$ \\
\hline \multirow[t]{2}{*}{$3^{\mathrm{z}}$} & Wheat & $0.490(0.039)$ & $0.496(0.035)$ & $0.492(0.038)$ \\
\hline & Onion & $-0.086(0.733)$ & $-0.108(0.671)$ & $-0.074(0.770)$ \\
\hline \multirow[t]{2}{*}{4} & Wheat & NA & $\ldots$ & $\ldots$ \\
\hline & Onion & NA & $\ldots$ & $\ldots$ \\
\hline \multirow[t]{2}{*}{8} & Wheat & $0.607(0.008)$ & $0.659(0.003)$ & $0.635(0.005)$ \\
\hline & Onion & $0.329(0.183)$ & $0.468(0.050)$ & $0.492(0.038)$ \\
\hline \multicolumn{5}{|l|}{2013} \\
\hline $2-1$ & Wheat & $0.257(0.303)$ & $0.272(0.273)$ & $0.291(0.241)$ \\
\hline 3 & Wheat & $0.599(0.009)$ & $0.608(0.007)$ & $0.567(0.014)$ \\
\hline 4 & Wheat & $0.082(0.745)$ & $0.084(0.742)$ & $0.065(0.942)$ \\
\hline 8 & Wheat & $0.002(0.992)$ & $0.033(0.897)$ & $0.011(0.966)$ \\
\hline
\end{tabular}

y NA = not applicable because DNA was not detected for that AG, except $R$. solani AG 2-1, which was detected only in one soil sample collected in dead wheat rows in the Paterson field in 2012. Values in parentheses are the probability values of the correlation coefficients. Probability values $\leq 0.05$ are in bold.

${ }^{\mathrm{z}}$ DNA concentration (pg/g of soil) was transformed to $\log (x+1)$ for soil samples collected in 2012. Refer to the main text for details on soil sampling, DNA extraction, and DNA quantification protocols. 
approximately the five-true-leaf stage of growth may be optimum in most years for assessing disease severity and potential yield impacts.

The greater concentration of $R$. solani AG 8 DNA detected in soil sampled from the dead or dying winter wheat cover crop rows compared with soil sampled from the live onion rows in the 2012 trial demonstrates that the large root mass of fall-sown winter wheat plants provides a significant amount of substrate on which the fungus can develop. In comparison, onion roots have very limited root hairs and much smaller root mass than wheat (Brewster 2008). In addition, $R$. solani AG 8 is a saprophyte as well as a pathogen, and can colonize dead or dying wheat roots readily because the roots have no resistance to infection once the plants are killed with an herbicide. The greater concentration of $R$. solani AG 8 DNA detected in the soil of the wheat rows than DNA of $R$. solani AG 2-1 and AG 3 in the wheat rows in 2012 confirmed that wheat cover crops can play a significant role in the buildup of $R$. solani AG 8 inoculum following herbicide application to kill a cover crop. In the onion rows, the DNA concentration of $R$. solani AG 3 and AG 8 did not differ significantly. However, the DNA concentration of $R$. solani AG 8 decreased in both the dead winter wheat cover crop rows and the live onion rows as the interval between herbicide application to the cover crop and onion planting increased. The mass of dead wheat roots provides a temporary food base for $R$. solani AG 8 to increase in the soil (Babiker et al. 2011; Smiley et al. 1992), causing more severe onion root infection and resultant stunting in plots in which herbicide was applied to the cover crop just prior to planting onion seed.

Consistent significant positive correlations between DNA concentration of $R$. solani AG 3 detected in the soil sampled from the wheat cover crop rows with the number of patches of stunted plants, cumulative patch area, and patch severity index in both the 2012 and 2014 trials suggests that $R$. solani AG 3 may be one of the causal agents of onion stunting in the Columbia Basin. R. solani AG 3 isolates collected from the Columbia Basin ranked as the most aggressive isolates after $R$. solani AG 8 isolates in a greenhouse study (Patzek et al. 2013). Greater numbers of $R$. solani AG 3 isolates were baited from soil sampled inside patches of stunted onion plants compared with soil sampled outside patches in another study in this region (Sharma-Poudyal et al. 2015b). R. solani AG 3 was also reported to be pathogenic on onion in New Zealand (Farrokhi-Nejad et al. 2007), but not in Australia (Wicks et al. 2011). In this study, the lack of significant correlations of DNA concentrations of $R$. solani AG 2-1 and AG 4 with onion stunting suggests these two AG may not be associated as significantly with onion stunting as $R$. solani AG 3 and AG 8. Sharma-Poudyal et al. (2015b) and Wicks et al. (2011) also did not observe a significant relationship between $R$. solani AG 2-1 DNA concentration and onion stunting. Although $R$. solani AG 4 was implicated as pathogenic on onion roots in Israel (Ichielevich-Auster et al. 1985), New Zealand (Farrokhi-Nejad et al. 2007), and Turkey (Erper et al. 2006), the lack of significant correlations between soil DNA concentration of $R$. solani AG 4 with onion stunting in this study supports previous studies that suggest that $R$. solani AG 4 is not a major cause of onion stunting in the Columbia Basin (Sharma-Poudyal et al. 2015b).

In this study in the Columbia Basin, a much greater mean concentration of $R$. solani AG 8 DNA was quantified in the dead wheat cover crop rows in the 2012 trial compared with the 2014 trial ( 15.95 versus $2.89 \mathrm{pg} / \mathrm{g}$ of soil, respectively). Likewise, significant positive correlations between $R$. solani AG 8 DNA concentration and onion stunting were detected in the 2012 trial but not in the 2014 trial. Although $R$. solani AG 8 isolates caused onion stunting at relatively lower inoculum levels than $R$. solani AG 3 isolates from the Columbia Basin in a greenhouse study (Patzek et al. 2013), R. solani AG 8 inoculum levels in the 2014 trial in this study might have been below a threshold for inducing stunting of onion plants. However, differences in soil sampling time for $R$. solani AGs relative to the onion crop maturity might have contributed to differences in the DNA concentration of $R$. solani AG 8 detected in the 2 years of this study. In the 2012 trial, soil was sampled on 11 June 2012, 56 days after the final herbicide application, whereas soil was sampled only 20 days after the last herbicide application in the 2014 trial.
In 2014, soil samples were collected that early to try and maximize the concentration of DNA detected for various $R$. solani AGs, given the transitory nature of $R$. solani AG 8 increase in soil following herbicide application to a cereal crop. In a barley trial, greater concentrations of DNA of $R$. solani AG 8 were detected in soil sampled within 7 days of a glyphosate application (Babiker et al. 2011).

Inoculum concentrations of $R$. solani AGs can be influenced by crop rotations (Rovira 1986; Rush and Winter 1990). Because onion is planted once every 3 to 4 years in rotation with other crops in the Columbia Basin, the specific crop rotation in a field may influence soilborne $R$. solani AG 8 concentration. The field in which the 2012 trial was done had been planted to a winter wheat cash crop from fall 2010 to summer 2011, prior to planting the winter wheat cover crop in October 2011. The wheat roots of the cash crop might have provided additional substrate to build inoculum of $R$. solani AG 8 , as detected in the 2012 onion trial. In contrast, the field in which the 2014 onion trial was set up had been planted to sweet corn in spring 2013, followed by the winter wheat cover crop planted in October 2013, and had relatively low concentrations of $R$. solani AG 8 detected in 2014. To our knowledge, sweet corn has not been reported to be as susceptible to $R$. solani AG 8 as wheat.

In conclusion, an increase in interval between glyphosate application to a winter wheat cover crop and onion seeding resulted in a significant decrease in onion stunting. Because dying roots of the winter wheat cover crop provide a substrate for colonization by $R$. solani AG 8, glyphosate application to a cover crop at least 3 weeks before onion seeding is recommended as a management tool to reduce the severity of onion stunting in fields with a high risk of this disease. The results of this study also suggest that isolates of $R$. solani AG 8 and AG 3 are involved in onion stunting in the Columbia Basin. The latter could be associated with the significant acreage of potato production in the area (Pelter and Sorensen 2003), because potato is a primary host of $R$. solani AG 3 (Carling and Leiner 1990).

\section{Acknowledgments}

We thank J. Eggers, S. Anstis, T. Wicks, A. Prescott, M. Derie, E. Christianson, and S. Mullahy for assistance in the study; D. Johnson and E. Babiker for reviewing the manuscript; and onion grower-cooperators in the Columbia Basin.

\section{Literature Cited}

Anstis, S. T., Wicks, T. J., and Pederick, S. 2012. Rhizoctonia solani AG-8 associated with stunted onion patches in South Australia. Acta Hortic. 969:247-253.

Babiker, E. M., Hulbert, S. H., Schroeder, K. L., and Paulitz, T. C. 2011. Optimum timing of preplant applications of glyphosate to manage Rhizoctonia root rot in barley. Plant Dis. 95:304-310.

Baley, G. J., Campbell, K. G., Yenish, J., Kidwell, K. K., and Paulitz, T. C. 2009. Influence of glyphosate, crop volunteer and root pathogens on glyphosateresistant wheat under controlled environmental conditions. Pest Manage. Sci. 65:288-299.

Brewster, J., ed. 2008. Onions and Other Vegetable Alliums. CAB International, Wallingford, UK.

Carling, D. E., and Leiner, R. H. 1990. Virulence of isolates of Rhizoctonia solani AG-3 collected from potato plant organs and soil. Plant Dis. 74:901-903.

Duke, S. O., Wedge, D. E., Cerdeira, A. L., and Matallo, M. B. 2007. Herbicide effects on plant disease. Pest Manage. Sci. 18:36-40.

du Toit, L. J., Sharma-Poudyal, D., Paulitz, T., Porter, L., Eggers, J., and Hamm, P. 2012. Onion stunting caused by Rhizoctonia: Management and economic importance in the Columbia Basin of Oregon and Washington. Pages 68-77 in: Proc. 2012 Nat. Allium Res. Conf., Las Cruces, NM.

Erper, I., Karaca, G. H., Turkkan, M., and Ozkoc, I. 2006. Characterization and pathogenicity of Rhizoctonia spp. from onion in Amasya, Turkey. Phytopathology 154:75-79.

Farrokhi-Nejad, R., Cromey, M. G., and Moosawi-Jorf, S. A. 2007. Determination of the anastomosis grouping and virulence of Rhizoctonia spp. associated with potato tubers grown in Lincoln, New Zealand. Pak. J. Biol. Sci. 10: 3786-3793.

Hosler, R. E. 1983. Soil survey report of Morrow County Area, Oregon. Technical report. USDA Soil Conservation Service, Washington, DC.

Ichielevich-Auster, M., Sneh, B., Koltin, Y., and Barash, I. 1985. Pathogenicity, host specificity and anastomosis groups of Rhizoctonia spp. isolated from soils in Israel. Phytoparasitica 13:103-112.

Johal, G. S., and Huber, D. M. 2009. Glyphosate effects on diseases of plants Eur. J. Agron. 31:144-152.

Johnson, D. R., and Makinson, A. J. 1988. Soil survey report of Umatilla County Area Oregon. Technical report. USDA Soil Conservation Service, Washington, DC. 
Larson, R. L., Hill, A. L., Fenwick, A., Kniss, A. R., Hanson, L. E., and Miller, S. D. 2006. Influence of glyphosate on Rhizoctonia and Fusarium root rot in sugar beet. Pest Manage. Sci. 62:1182-1192.

Lévesque, C. A., and Rahe, J. E. 1992. Herbicide interactions with fungal root pathogens with special reference to glyphosate. Annu. Rev. Phytopathol. 30:579-602.

Ophel-Keller, K., Mackay, A., Hartley, H., and Curran, J. 2008. Development of a routine DNA-based testing service for soilborne diseases in Australia. Australas. Plant Pathol. 37:243-253.

Patzek, L. J., du Toit, L. J., Paulitz, T. C., and Jones, S. S. 2013. Stunting of onion in the Columbia Basin of Oregon and Washington caused by Rhizoctonia spp. Plant Dis. 97:1626-1635.

Paulitz, T. C., Smiley, R. W., and Cook, R. J. 2002. Insights into the prevalence and management of soilborne cereal pathogens under direct seeding in the Pacific Northwest, USA. Can. J. Plant Pathol. 24:416-428.

Pelter, G. Q., and Sorensen, E. J. 2003. Crop Profile for Onions in Washington. Technical report. Regional Integrated Pest Management Centers, United States Department of Agriculture, http://www.ipmcenters.org/cropprofiles/docs/ WAonions.pdf (last accessed Feb. 2016).

Rashid, A., Hwang, S. F., Ahmed, H. U., Turnbull, G. D., Strelkov, S. E., and Gossen, B. D. 2013. Effects of soil-borne Rhizoctonia solani on canola seedlings after application of glyphosate herbicide. Can. J. Plant Sci. 93: 97-107.

Roget, D. K., Venn, N. R., and Rovira, A. D. 1987. Reduction of Rhizoctonia root rot of direct-drilled wheat by short-term chemical fallow. Anim. Prod. Sci. 27: 425-430.

Rovira, A. D. 1986. Influence of crop rotation and tillage on Rhizoctonia bare patch of wheat. Phytopathology 76:669-673.

Rush, C. M., and Winter, S. R. 1990. Influence of previous crops on Rhizoctonia root and crown rot of sugar beet. Plant Dis. 74:421-425.

Schillinger, W. F., Papendick, R. I., and McCool, D. K. 2010. Soil and water challenges for Pacific Northwest agriculture. Pages 47-79 in: Soil and Water Conservation Advances in the United States. Soil Sci. Soc. Am. Spec. Publ. 60. T. M. Zobeck and W. F. Schillinger, eds. Soil Science Society of America, Madison, WI.

Sharma-Poudyal, D., Eggers, J., Paulitz, T. C., Hamm, P., and du Toit, L. J. 2014a. Effect of deep vs. shallow tillage on onion stunting and onion bulb yield, 2012. Plant Dis. Manage. Rep. 8:V306.
Sharma-Poudyal, D., Paulitz, T. C., and du Toit, L. J. 2015a. Evaluation of onion genotypes for resistance to stunting caused by Rhizoctonia solani AG 8 . HortScience 50:551-554.

Sharma-Poudyal, D., Paulitz, T. C., and du Toit, L. J. 2015b. Stunted patches in onion bulb crops in Oregon and Washington: Etiology and yield loss. Plant Dis. 99:648-658

Sharma-Poudyal, D., Paulitz, T. C., Linderman, R. G., and du Toit, L. J. 2014b. Effect of arbuscular mycorrhizal fungi on onion growth and onion stunting caused by Rhizoctonia solani, 2013. Plant Dis. Manage. Rep. 8:V305.

Sharma-Poudyal, D., Paulitz, T. C., Porter, L. D., and du Toit, L. J. 2015c Characterization and pathogenicity of Rhizoctonia and Rhizoctonia-like species from pea crops in the Columbia Basin of Oregon and Washington. Plant Dis. 99:604-613.

Sharma-Poudyal, D., Paulitz, T. C., Porter, L., Eggers, J., Hamm, P. B., and du Toit, L. 2013a. Effect of timing of glyphosate application to a winter wheat cover crop on stunting of spring-sown onions caused by Rhizoctonia spp. in the Columbia Basin of Washington, 2012. Plant Dis. Manage. Rep. 7:V046.

Sharma-Poudyal, D., Paulitz, T. C., Porter, L., Eggers, J., Hamm, P. B., and du Toit, L. J. 2013b. Efficacy of fungicides to manage onion stunting caused by Rhizoctonia spp. in the Columbia Basin of Oregon and Washington, 2011-2012. Plant Dis. Manage. Rep. 7:V047.

Sharma-Poudyal, D., Paulitz, T. C., Porter, L., Eggers, J., Hamm, P. B., and du Toit, L. J. 2013c. Yield responses of three onion cultivars to stunting caused by Rhizoctonia spp. in the Columbia Basin of Oregon and Washington, 2012. Plant Dis. Manage. Rep. 7:V048.

Sharma-Poudyal, D., Paulitz, T.C., Porter, L., Eggers, J., Hamm, P.B., and du Toit, L. J. 2013d. Rhizoctonia spp. dynamics and optimal timing of glyphosate application to cereal cover crops to manage onion stunting in Washington and Oregon. (Abstr.) Phytopathology 103:S2.131.

Smiley, R. W., Ogg, A. G., Jr., and Cook, R. J. 1992. Influence of glyphosate on Rhizoctonia root rot, growth, and yield of barley. Plant Dis. 76:937-942.

Sneh, B., Burpee, L., and Ogoshi, A. 1991. Identification of Rhizoctonia Species. American Phytopathological Society Press, St. Paul, MN.

United States Department of Agriculture National Agricultural Statistics Service. 2012. Vegetables 2011 summary. Tech. Rep. January 2012.

Wicks, T., Walker, G., Pederick, S., and Anstis, S. 2011. Onion stunting in South Australia associated with Rhizoctonia solani AG 8. Australas. Plant Pathol. 40 126-132. 